\title{
Diagnostische benadering van cryptorchidie bij de hengst
}

\author{
Diagnostic approach of the cryptorchid stallion
}

\author{
${ }^{1}$ L. De Lange, ${ }^{1}$ K. Roels, ${ }^{1} \mathrm{C}$. Ververs, ${ }^{1} \mathrm{M}$. Van de Velde, ${ }^{2} \mathrm{P}$. Corty, ${ }^{1} \mathrm{~J}$. Govaere \\ ${ }^{1}$ Vakgroep Voortplanting, Verloskunde en Bedrijfsdiergeneeskunde, Faculteit Diergeneeskunde, Universiteit \\ Gent, Salisburylaan 133, B-9820 Merelbeke, Belgium \\ ${ }^{2}$ Dierenartsenpraktijk “Ter Dieschoot”, Hoogstraat 30-32 B-8730 Oedelem-Beernem, Belgium
}

Lisa.DeLange@ugent.be

\section{AMENVATTING}

De diagnose van cryptorchidie bij het paard is vaak een uitdaging aangezien niet altijd definitief uitsluitsel kan gegeven worden op basis van de anamnese, het klinische onderzoek en het rectaal en echografisch onderzoek. Verschillende endocrinologische diagnostische testen zoals de bepaling van het testosteron-, androstenedione-, oestrogenen-, urinaire steroïden- en het antimülleriaans hormoongehalte, die de aanwezigheid van testiculair weefsel aantonen, zijn beschreven. In dit artikel wordt getracht om de voor- en nadelen van deze testen te vergelijken, zodat practici een idee krijgen welke testen in de praktijk gebruikt kunnen worden.

\section{ABSTRACT}

The diagnosis of cryptorchidism in horses is often a challenge. Based on the history, clinical and rectal examinations and ultrasonography, a definitive diagnosis is not always possible. Various endocrinological diagnostic assays, such as the determination of testosterone, androstenedione, estrogens, urinary steroids and the anti-Müllerian hormone, which demonstrate the presence of testicular tissue, have been described. These tests all have their advantages and disadvantages, which are discussed in this article in order to help practitioners in the field.

\section{INLEIDING}

Bij het veulen dalen de testikels, die zich tijdens de embryonale ontwikkeling caudaal van de nieren bevinden, dertig dagen vóór de geboorte tot twee weken na de geboorte tot in het scrotum (Kristina, 2005). Cryptorchidie of het niet-indalen van één of beide testikels is om verscheidene redenen ongewenst en wordt veelal door middel van castratie verholpen. Door het erfelijke karakter van de aandoening worden dieren met cryptorchidie geweerd uit de fokkerij (Hayes, 1986). Deze afwijking wordt gezien bij 5-8\% van de veulens en is meestal unilateraal (Arighi, 2011). Het komt meer voor bij de rassen percheron, saddlebred, quarter horse, bij pony's en bij gekruiste rassen. Bij volbloeden, standardbreds, morgans, Tennessee walking horses en Arabische volbloedrassen daarentegen wordt cryptorchidie minder frequent gezien (Hayes, 1986). Wanneer slechts één testikel is ingedaald (unilaterale cryptorchidie) zijn de paarden meestal vruchtbaar; bilaterale cryptorchen daarentegen zijn steriel (Arighi, 2011). In veertien procent van de gevallen waarbij cryptorchidie vastgesteld wordt, zijn beide testikels niet ingedaald (Hayes, 1986). De niet-ingedaalde testikels kunnen zich intra-abdominaal of inguinaal bevinden. Een laattijdige indaling, op twee- à driejarige leeftijd wordt beschreven maar wordt weinig waarschijnlijk geacht (Cox, 1979). In het geval van inguinale lokalisatie is het meestal de rechtertestikel die niet indaalt, terwijl bij intra-abdominale cryptorchidie het meestal de linkertestikel betreft (Stickle, 1978). Bij pony's is het omgekeerd: de linkertestikel bevindt zich meestal inguinaal en de rechter intra-abdominaal (Kristina, 2005).

De differentiatie tussen een bilateraal gecastreerde hengst of een bilateraal cryptorche hengst (of een unilateraal gecastreerde, unilaterale cryptorch) kan bij paarden met een onbekende voorgeschiedenis of een gebrekkige anamnese een uitdaging vormen.

Waar bij volledig inguinale lokalisatie van de cryptorche testikel de diagnose nog door uitwendige palpatie kan worden gesteld, is bij een intra-abdominale, evenals bij een onvolledig inguinale cryptorch (waarbij de epididymis in het inguinale kanaal ingedaald is terwijl de testikel zich nog intra-abdominaal bevindt), de palpatie moeilijker. Transrectale of transcutane echografie kan worden aangewend, maar gezien de cryptorche testikel veelal hypoplastisch is, kan deze 
Tabel 1. De testosterongrenswaarden en beperkingen bij de diagnosestelling van cryptorchidie bij het paard. Testosteronwaarde: $\mathrm{nmol} / \mathrm{l} / \mathbf{3 , 4 7}=\mathrm{ng} / \mathrm{ml}$ (Smith et al., 2008).

\begin{tabular}{|c|c|c|c|c|c|c|c|}
\hline Hormoon & Staal & Sensitiviteit & Specificiteit & Hengst & Cryptorch & Ruin & Beperkingen \\
\hline Testosteron & Serum & $0,85^{3}$ & $0,91^{3}$ & $\begin{array}{l}>500 \mathrm{pg} / \mathrm{ml}^{1} \\
65-1600 \mathrm{pg} / \mathrm{ml}^{2}\end{array}$ & $\begin{array}{l}<200 \mathrm{pg} / \mathrm{ml}^{1} \\
<50-100 \mathrm{pg} / \mathrm{ml}^{2}\end{array}$ & $\begin{array}{l}50-500 \mathrm{pg} / \\
\mathrm{ml}^{2}\end{array}$ & $\begin{array}{l}\text { Meerdere stalen } \\
\text { noodzakelijk, } \\
+\mathrm{hCG} \text {, } \\
14 \% \text { valspos. of } \\
\text {-neg. resultaten }\end{array}$ \\
\hline
\end{tabular}

1: Mc Cue 2014. De testosteronconcentratie bekomen na hCG-stimulatie bij de hengst, ruin en cryptorch verschilt naargelang de studie. Indien er testiculair weefsel aanwezig is, dan verdubbelt of verviervoudigt de testosteronconcentratie ten opzichte van de basale waarde (i.e. vóór de toediening van hCG). Deze stijging is diagnostisch van belang, niet de waarde zelf. ${ }^{2}$ : Cox et al., 1973; ${ }^{3}$ Illera et al., 2003 ${ }^{8}$ Mueller et al., 1999

diagnostische methode niet steeds uitsluitsel geven. Hengsten zijn doorgaans minder gewend aan rectaal onderzoek, hetgeen het onderzoek meer risicovol kan maken. Daarenboven is bij minirassen de rectale benadering meestal niet mogelijk.

Waar palpatie of echografisch onderzoek tekortschiet, kan veelal definitief uitsluitsel gegeven worden door middel van endocrinologische testen. In dit artikel wordt een overzicht gegeven van de verschillende endocrinologische, diagnostische mogelijkheden, elk met hun specificiteit en sensitiviteit.

\section{ENDOCRINOLOGISCHE TESTEN}

\section{Testosteron}

Testosteron is een hormoon dat voornamelijk geproduceerd wordt ter hoogte van de leydigcellen van de testes als respons op de pulsatiele secretie van het luteïniserend hormoon (LH) uit de hypofyse (Odell, 1989). Bij de hengst is het testosterongehalte in het bloed individueel verschillend (Pineda, 2003). Het is seizoens- en leeftijdsafhankelijk met de laagste concentraties van september tot januari (Naden et al., 1990). Tijdens de puberteit, rond de leeftijd van 68 weken, vindt een trage stijging van het testosterongehalte plaats en dit tot de leeftijd van 75-80 weken (Naden et al., 1990; Clay et al., 1992). Nadien varieert de concentratie in functie van het seizoen en het moment van de dag.

Het is van belang om het testosterongehalte te bepalen in het bloed. Kleine hoeveelheden testosteron kunnen ook gevonden worden in de urine van ruinen, wat waarschijnlijk het gevolg is van de biosynthese ter hoogte van de adrenale cortex (Silberzahn et al., 1984).

De serum-testosteronconcentratie bij hengsten is meestal hoger dan 500-1000 pg/ml $(0,5-1,0 \mathrm{ng} / \mathrm{ml})$ (Mc Cue, 2014), hoewel minima van 65 en maxima van $1600 \mathrm{pg} / \mathrm{ml}$ ook worden vermeld (Cox et al., 1973). Bij een ruin daarentegen is de concentratie lager dan $50-100 \mathrm{pg} / \mathrm{ml}(0,05-0,10 \mathrm{ng} / \mathrm{ml})$, terwijl de testosteronconcentratie bij een cryptorche hengst, tussen beide waarden ligt (50-500 pg/ml), maar veelal minder dan $200 \mathrm{pg} / \mathrm{ml}$ bedraagt (Mc Cue, 2014).
Soms worden overlappende waarden waargenomen zoals lage testosteronconcentraties bij hengsten en hoge bij ruinen (Cox et al., 1973). In twee studies van Arighi et al. $(1985 ; 1989)$ werd geconcludeerd dat een waarde van $<0,24 \mathrm{ng} / \mathrm{ml}$ diagnostisch is voor de afwezigheid van testiculair weefsel, terwijl concentraties van $>0,44 \mathrm{ng} / \mathrm{ml}$ indicatief zijn voor de aanwezigheid van testiculair weefsel (Arighi et al., 1985; Arighi et al., 1989). Bij waarden tussen 0,24 ng/ml en 0,44 ng/ $\mathrm{ml}$ wordt een andere diagnostische methode aangeraden (Tabel 1).

Gonadotropine releasing hormoon $(\mathrm{GnRH})$, en dus ook LH, worden in pulsen vrijgesteld, waardoor het testosterongehalte in de loop van de dag schommelt (Nett, 1993). In de ochtend is de concentratie het laagst, waarna ze toeneemt en rond de middag het hoogst is (McCue, 2014). Een eenmalige testosteronbepaling is dus weinig informatief. Indien er maar één bloedstaal genomen wordt, wordt dit het beste gedaan in de vroege namiddag, op het moment dat de circulerende hormonen het hoogst zijn (McCue, 2014).

Door de diurnale en seizoensvariatie is een bepaling van de testosteronconcentratie na een hCG-stimulatietest meer aangewezen (Cox et al., 1975). In tegenstelling tot ruinen, waarbij geen respons waarneembaar is, vertonen hengsten en cryptorchen een graduele stijging van de testosteronconcentratie in het serum na hCG-stimulatie (Silberzahn et al., 1989). Deze stijging is het gevolg van een verhoogde secretie van testosteron door de leydigcellen na hCGstimulatie (Amann, 1981). Wat van belang is bij de hCG-stimulatietest is de stijging van de concentratie ten opzichte van de basale waarde. Deze stijging is variabel en kan na 0 tot 120 minuten verdubbelen tot verviervoudigen (McCue, 2014). De locatie van de testis, de leeftijd van het dier, evenals het moment van staalname (dagritme, seizoen) beïnvloeden de respons na hCG-toediening (Cox et al., 1975; Arighi et al., 1985; Arighi et al., 1989).

De hCG-stimulatietest kan op twee verschillende manieren uitgevoerd worden (McCue, 2014). De eerste manier betreft een eenmalige bloedafname vóór een injectie van hCG, om de basale testosteronwaarde te bepalen, waarna 6-12 000IU hCG IV worden toegediend. Eén en twee uur na de behandeling wordt telkens een bloedstaal genomen. Gezien de soms laat- 
Tabel 2. Androstenedionegrenswaarden en -beperkingen bij de diagnosestelling van cryptorchidie bij het paard.

\begin{tabular}{|c|c|c|c|c|c|c|c|}
\hline Hormoon & Staal & Sensitiviteit & Specificiteit & Hengst & Cryptorch & Ruin & Beperkingen \\
\hline Androstenedione & Serum & $0,92^{3}$ & $0,93^{3}$ & $\begin{array}{l}10,52 \mathrm{ng} / \mathrm{ml}^{3} \\
0,55-0,70 \mathrm{ng} / \\
\mathrm{ml}^{2}\end{array}$ & $\begin{array}{l}0,51 \mathrm{ng} / \mathrm{ml}^{3} \\
0,180-0,350 \mathrm{ng} / \\
\mathrm{ml}^{2}\end{array}$ & $\begin{array}{l}0,03 \mathrm{ng} / \mathrm{ml}^{3} \\
0,079-0,081 \mathrm{ng} / \\
\mathrm{ml}^{2}\end{array}$ & $\begin{array}{l}\text { niet routinematig } \\
\text { aangeboden }\end{array}$ \\
\hline
\end{tabular}

Cox et al., 1973; ${ }^{3}$ Illera et al., 2003

tijdige reactie bij abdominaal cryptorche dieren wordt er 24 uur na de hCG-toediening een derde staal genomen. De diagnose van testiculair weefsel hangt af van de stijging in plasmatestosteron na hCG-stimulatie.

Een tweede protocol behelst een bloedafname dertig minuten vóór de toediening van $10000 \mathrm{IU}$ hCG evenals op het moment van de toediening. Vervolgens wordt er om de dertig minuten bloed afgenomen en dit tot drie uur na de toediening.

Echter, Illera et al. (2003) toonden aan dat bij de bepaling van testosteron na stimulatie een hoog aantal $(15 \%)$ valsnegatieve resultaten gevonden wordt, met een lage, negatief voorspellende waarde $(0,85)$ en een lage sensitiviteit $(0,85)$ in vergelijking met oestronsulfaat- en androstenedione-detectie (Illera et al., 2003) voor wat betreft de aanwezigheid van testiculair weefsel. Ook in een studie van Cox et al. (1986) konden de resultaten in $6,7 \%$ van de gevallen niet eenduidig geïnterpreteerd worden.

\section{ANDROSTEENDION}

Androsteendion is, zowel bij mannelijke (in de testes) als vrouwelijke (in de ovaria) dieren, een precursorhormoon van androgenen en oestrogenen. Het is betrokken bij de regulatie van onder andere de puberteit, de controle van de folliculaire groei en de mannelijke, reproductieve fysiologie (Inoue et al., 1993; Muyan et al., 1993; Hoffman en Landeck, 1999). De androsteendionconcentratie in het serum kan bepaald worden aan de hand van een "amplified enzyme immunoassay" (Illera et al., 2003). De concentratie is het hoogst bij de hengst en het laagst bij de ruin. Cryptorchen hebben een concentratie tussen die van hengst en ruin (Tabel 2). Er werd aangetoond dat de bepaling van androsteendion samengaat met een hogere sensitiviteit $(0,92)$ en specificiteit $(0,93)$, en dat de test efficiënter $(0,92)$ is dan de bepaling van testosteron en oestronsulfaat. De meeste commerciële labo's bieden deze analyse echter niet aan (Tabel 2).

\section{URINAIRE STEROÏDEN}

De diagnose van cryptorchidie kan ook gesteld worden wanneer de steroïden $5(10)$-estrene- $3 \beta, 17 \alpha$ diol en/of 4-estren-3,17-dion in de urine van vermeende ruinen aanwezig zijn. 5(10)-Estren-3 $\beta, 17 \alpha$ diol kan niet worden aangetoond in de urine van de ruin en 4-estren-3,17-dion is in een grotere concentra- tie aanwezig bij hengsten en cryptorchen. Deze twee steroïden worden geproduceerd tijdens de biosynthese van androgenen en worden gedetecteerd aan de hand van gaschromatografie en een massaspectrometrietest (Leung et al., 2011). Deze test is in tegenstelling tot de bepaling van estronsulfaat toepasbaar bij paarden vanaf twee jaar. Bovendien kunnen ook andere testiculaire, steroïdale merkers aangetoond worden, onder andere testosteron, nandrolon, estron en $17 \beta$-estradiol. Deze vier zijn echter minder specifiek maar indien ze in grote hoeveelheden aanwezig zijn in de urine, kunnen ze gebruikt worden als bijkomend bewijs voor de aanwezigheid van testiculair weefsel (Leung et al., 2011). Dergelijke analyses worden echter niet standaard aangeboden in hematologische routinelaboratoria.

\section{OESTROGENEN}

Oestrogenen worden na aromatisatie gevormd uit testosteron. Dit vindt bij de hengst, in tegenstelling tot bij andere diersoorten, plaats ter hoogte van het testiculaire weefsel (Pineda, 2003). Of dit aromatisatieproces plaatsvindt ter hoogte van de sertoli- en/of de leydigcellen is nog een punt van discussie (Hejmej et al., 2005). De gevormde oestrogenen kunnen onderverdeeld worden in gebonden oestrogenen na conjugatie, d.i. oestronsulfaat, en ongebonden oestrogenen of oestradiol $17 \beta$ (Schonert et al., 2012). Achtennegentig procent van de geproduceerde oestrogenen is gebonden oestrogeen (Raeside, 1978). Oestradiol $17 \beta$ heeft invloed op meerdere orgaansystemen en zou verantwoordelijk zijn voor het hengstengedrag (Schonert et al., 2012). Zoals dit het geval is voor testosteron is ook de concentratie van oestrogenen in het bloed verschillend tijdens het jaar. De concentratie is het hoogst in mei en het laagst in november en december (Raeside, 1978), wat samenhangt met het voortplantingsseizoen van paarden. De intratesticulaire hoeveelheid oestradiol stijgt met de testiculaire maturatie (Stewart en Roser, 1998).

De bepaling van de hoeveelheid oestrogenen kan ook waardevol zijn bij het diagnosticeren van een cryptorch. Aangezien $98 \%$ van de geproduceerde oestrogenen gebonden is (Raeside, 1978), is het bepalen van ongebonden oestrogenen niet relevant. De bepaling van plasma-oestronsulfaat aan de hand van een radio-immuno-assay (RIA) wordt aangewend als diagnostisch middel voor het aantonen van testiculair weefsel. Wanneer de gemeten concentraties hoger 
zijn dan $400 \mathrm{pg} / \mathrm{ml}$, is het paard zeker cryptorch (Silberzahn et al., 1989). Indien de waarde lager is dan 50 $\mathrm{pg} / \mathrm{ml}$, is het paard zeker een ruin. Voor waarden tussen dit interval is een andere diagnostische test aangewezen. Deze test is niet toepasbaar bij paarden jonger dan drie jaar aangezien de testiculaire productie van oestronsulfaat verwaarloosbaar is bij jonge hengsten (Gaillard en Silberzahn, 1987). Afhankelijk van de gebruikte antilichamen in de verschillende testen worden echter verschillende drempelwaarden waargenomen. In een studie van Arighi en Bosu (1989) was de oestronsulfaatconcentratie $<0,12 \mathrm{ng} / \mathrm{ml}(<0,34$ $\mathrm{nmol} / \mathrm{l})$ bij ruinen en $>1 \mathrm{ng} / \mathrm{ml}(>2,85 \mathrm{nmol} / \mathrm{l})$ bij dieren met testiculair weefsel. Palme et al. (1994) daartegen beschreven bij deze dieren hogere concentraties (respectievelijk $<3,5 \mathrm{nmol} / 1$ en $>37 \mathrm{nmol} / \mathrm{l}$ ) (Tabel $3)$. Een voorafgaande injectie met hCG heeft weinig zin daar hCG bijna geen kortetermijneffect vertoont op oestrogenen van hengsten en cryptorchen (Ganjam en Kenney, 1975). Unilaterale cryptorchen hebben een hogere $(p<0,05)$ concentratie geconjugeerde oestrogenen in het bloed dan bilateraal of unilateraal gecastreerde paarden (Palme, 1994). Bij de ezel kan de diagnose van cryptorchidie aan de hand van oestronsulfaat niet gebruikt worden, aangezien deze geen geconjugeerde oestrogenen hebben (Cox et al., 1986).

In een studie van Illera et al. (2003) werd de concentratie van oestronsulfaat in het serum vergeleken met deze van testosteron en androsteendion. Uit deze vergelijking bleek dat de positief voorspellende waarde $(0,85)$ voor oestronsulfaat lager was, de hoeveelheid valspositieve resultaten hoger en de specificiteit lager dan voor beide andere hormonen, wat betreft de aanwezigheid van testiculair weefsel.

De bepaling van fecale ongeconjugeerde oestrogenen kan ook gebruikt worden als diagnostisch middel. In een studie van Palme et al. (1994) werden hengsten, ruinen en cryptorchen onderzocht. De hoeveelheid fecale oestrogenen bij de hengsten was gemiddeld 130 $\mathrm{nmol} / \mathrm{kg}$, terwijl dit bij de ruinen gemiddeld $12 \mathrm{nmol} /$ $\mathrm{kg}$ was. De hengsten met één niet-ingedaalde testikel hadden een gemiddelde concentratie van $113 \mathrm{nmol} / \mathrm{kg}$ en de hengsten waarbij beide testikels niet ingedaald waren $64 \mathrm{nmol} / \mathrm{kg}$ (Tabel 3). Paarden met minstens één scrotale testikel hebben dus significant hogere $(p<0,05)$, fecale oestrogeenconcentraties dan cryp- torchen zonder scrotale testes (Palme et al.,1994). Dit wijst erop dat niet-ingedaalde testes minder oestrogenen produceren (Cox et al., 1986). Het oestrogenengehalte van deze paarden met minstens één scrotale testikel is nagenoeg gelijk aan deze bij hengsten, waardoor de aan- of afwezigheid van een cryptorche testes bij paarden met een normale intrascrotale testikel niet gediagnosticeerd kan worden (Palme, 1994). Ook deze test is niet bruikbaar bij paarden jonger dan twee jaar (Palme et al., 1994). Aangezien de oestrogeenconcentratie in feces varieert gedurende de dag, wordt aangeraden meer dan één fecesstaal te analyseren voor de bepaling van de oestrogeenconcentratie (Palme et al., 1994). Fecale oestrogenen zijn gedurende minstens één week stabiel en kunnen dus opgestuurd worden naar het labo waar ze aan de hand van een radio-immuno-assay onderzocht worden (Choi, 1987). De accuraatheid van de bepaling van fecale oestrogenen komt overeen met de accuraatheid van de bepaling van de concentratie van testosteron (na hCG-stimulatie) en de bepaling van oestronsulfaat in het bloed (Palme et al., 1994).

Naast de bepaling van oestrogenen in bloed en feces kan ook de hoeveelheid oestrogenen in de urine bepaald worden om de aanwezigheid van testiculair weefsel te bevestigen. De hoeveelheid oestrogenen in de urine stijgt van november tot mei (Palme et al., 1998). Bij ruinen is de gemiddelde oestrogenenconcentratie in de urine $11,3 \mathrm{nmol} / \mathrm{l}$. Zowel bij hengsten als bij cryptorchen is de gemiddelde concentratie 2000 tot 10000 maal hoger (respectievelijk $14500 \mathrm{nmol} / 1$ en 66000 nmol/l) (Palme et al., 1998) (Tabel 3).

\section{SERUM-ANTIMÜLLERIAANS HORMOON}

Het antimülleriaans hormoon (AMH) is een glycoproteïne gelinkt aan een disulfide dat behoort tot de "transforming growth factor beta"-familie. Bij mannelijke dieren wordt het in het vroege foetale leven gesecreteerd door de sertolicellen. In de prepuberale testes is de hoeveelheid lager (Ball et al., 2008; Almeida et al., 2012).

De normale sertolicelmaturatie in de testis gaat gepaard met een gedaalde AMH-expressie (Almeida et al., 2012). In de niet-ingedaalde testis vindt de matu-

Tabel 3. Oestrogeengrenswaarden en -beperkingen bij de diagnosestelling van cryptorchidie bij het paard.

\begin{tabular}{|c|c|c|c|c|c|c|c|}
\hline Hormoon & Staal & Sensitiviteit & Specificiteit & Hengst & Cryptorch & Ruin & Beperkingen \\
\hline \multirow[t]{3}{*}{ Oestrogenen } & $\begin{array}{l}\text { Serum } \\
\text { (Oestone) }\end{array}$ & $0,88^{3}$ & $0,84^{3}$ & $\begin{array}{l}175 \mathrm{ng} / \mathrm{ml}^{3} \\
45-60 \mathrm{ng} / \mathrm{ml}^{4}\end{array}$ & $\begin{array}{l}58,53 \mathrm{ng} / \mathrm{ml}^{3} \\
0,30-0,55 \\
\mathrm{ng} / \mathrm{ml}^{4}\end{array}$ & $\begin{array}{l}0,07 \mathrm{ng} / \mathrm{ml}^{3} \\
0,025-0,035 \\
\mathrm{ng} / \mathrm{ml}^{4}\end{array}$ & $\begin{array}{l}\text { Niet toepasbaar } \\
\text { bij paarden }<3 \text { jaar }\end{array}$ \\
\hline & Urine & - & - & $145000 \mathrm{nmol} / 1^{7}$ & $66000 \mathrm{nmol} / \mathrm{l}^{7}$ & $11,3 \mathrm{nmol} / 1^{7}$ & \\
\hline & Feces & - & - & $130 \mathrm{nmol} / \mathrm{kg}^{5}$ & $\begin{array}{l}\text { Unilat.: } \\
113 \mathrm{nmol} / \mathrm{kg}^{5} \\
\text { bilat.: } \\
64 \mathrm{nmol} / \mathrm{kg}^{5}\end{array}$ & $12 \mathrm{nmol} / \mathrm{kg}^{5}$ & $\begin{array}{l}\text { Niet toepasbaar } \\
\text { bij paarden } \\
<2 \text { jaar }\end{array}$ \\
\hline
\end{tabular}

${ }^{3}$ : Illera et al., 2003; ${ }^{4}$ : Silberzahn et al., 1989; ${ }^{\text {: }}$ Palme, 1994; ${ }^{7}$ : Palme et al., 1998 
Tabel 4. Grenswaarden en beperkingen van het antimülleriaans hormoon bij de diagnosestelling van cryptorchidie bij het paard.

\begin{tabular}{llllll}
\hline Hormoon & Staal & Hengst & Cryptorch & Ruin & Beperkingen \\
\hline AMH & Serum & $15 \mathrm{ng} / \mathrm{ml}^{6}$ & $32,5 \mathrm{ng} / \mathrm{ml}^{6}$ & $<$ detectielimiet & $\begin{array}{l}\text { niet toepasbaar bij prepuberale } \\
\text { dieren }^{6}\end{array}$ \\
\hline
\end{tabular}

${ }^{6}$ : Claes et al., 2013; ${ }^{9}$ Ball et al., 2008

ratie van sertolicellen onvoldoende plaats (Almeida et al., 2012), waardoor de hoeveelheid AMH in het serum, bepaald aan de hand van een "enzyme linked immunosorbent assay" (ELISA), bij een cryptorch hoger is dan bij een hengst (Claes et al., 2013). De AMHconcentratie bij ruinen ligt onder de detectielimiet. $\mathrm{Er}$ dient opgemerkt te worden dat de hoeveelheid AMH bij een cryptorch dezelfde is als deze bij hengstenveulens vóór de puberteit (Ball et al., 2008; Almeida et al., 2012). Naast leeftijd heeft ook het seizoen een invloed op de $\mathrm{AMH}$-concentratie, met een piek in mei en een dieptepunt in november (Claes et al., 2013).

Gemiddeld is het gehalte aan AMH in het bloed bij intacte hengsten 13,3 $\pm 1,8 \mathrm{ng} / \mathrm{ml}$ (range $1,7 \mathrm{ng} / \mathrm{ml}$ en $21,9 \mathrm{ng} / \mathrm{ml}$ ) (Murase, 2015), met hogere waarden in mei en juni (Claes et al., 2013). Deze stijging komt overeen met de stijging van de gonadotropinen en de steroïd hormonen (Taya et al., 2000). De hoeveelheid $\mathrm{AMH}$ bij een unilaterale (hemi-gecastreerde) hengst is $17,6 \pm 3,0 \mathrm{ng} / \mathrm{ml}$ (range $3,1 \mathrm{ng} / \mathrm{ml}$ en $28,2 \mathrm{ng} / \mathrm{ml}$ ) (Murase, 2015). Claes et al. (2013) rapporteerde gelijkaardige waarden van $15 \mathrm{ng} / \mathrm{ml}$ bij de hengst en $32,5 \mathrm{ng} / \mathrm{ml}$ bij een cryptorch (Tabel 4). Deze kleine verschillen kunnen te wijten zijn aan verschillen in leeftijd en de aan- of afwezigheid van een tweede testikel (Murase, 2015). In sommige gevallen wordt aangetoond dat cryptorche dieren met een testosteronconcentratie die duidt op de afwezigheid van testiculair weefsel, toch een positieve AMH-test vertoonden. De bepaling van AMH is dus een belangrijk middel in het geval van twijfelachtige gevallen (Claes et al., 2014). De AMH-concentratie is hoger bij bilaterale cryptorchen dan bij unilaterale cryptorchen.

\section{CONCLUSIE}

Iedere diagnostische methode heeft zijn waarde. De drie meest bruikbare endocrinologische methoden in de praktijk zijn de bepaling van de basale testosteronconcentratie, de hCG-stimulatietest en de bepaling van $\mathrm{AMH}$. De bepaling van geconjugeerde oestrogenen is $96 \%$ accuraat voor de bepaling van cryptorchidisme (Arighi et al., 1989) maar niet bruikbaar bij jonge dieren. Wanneer men een cryptorch wenst te onderscheiden van een ruin aan de hand van de bepaling van de basale testosteronconcentratie, wordt er in $14 \%$ van de gevallen een verkeerde diagnose gesteld (Mueller et al., 1999). De bepaling van de testosteron- concentratie na de hCG-stimulatietest is $94,6 \%$ accuraat voor het aantonen van testiculair weefsel (Cox, 1975). In tegenstelling tot de productie van testosteron vindt de productie van AMH alleen plaats ter hoogte van de sertolicellen. De bepaling van AMH is dus specifieker voor de diagnose van testiculair weefsel (Claes et al., 2014). Een bijkomend voordeel is dat er maar één staal nodig is voor de bepaling van $\mathrm{AMH}$, dit in tegenstelling tot de bepaling van testosteron na hCG-stimulatie, waarbij meerdere stalen nodig zijn (Claes et al., 2014). Er dient opgemerkt te worden dat er bij de interpretatie van hormonale resultaten rekening moet gehouden worden met de referentiewaarden en de verschillende detectiemethoden die gebruikt worden door de verschillende laboratoria (Mueller et al., 1999).

\section{REFERENTIES}

Almeida, J., Conley, A.J., Mathewson, L., Ball, B.A. (2012). Expression of anti-Müllerian hormone, cyclin-dependent kinase inhibitor (CDKN1B), androgen receptor and connexin 43 in equine testes during puberty. Theriogenology 77, 847-857.

Amann R.P., Ganjam V.K. (1981). Effects of hemicastration of hCG: treatement on steroids in testicular vein and jugular vein blood of stallions. Journal of Andrology 3, 132-139.

Arighi M. (2011). Testicular descent. In: McKinnon, A.O., et al. (editors). Equine Reproduction. Second edition, Blackwell publishing, West Sussex, 1099-1106.

Arighi M., Bosu W.T.K., Raeside J.I. (1985). Hormonal diagnosis of equine cryptorchidism and histology of the retained testes. In: Proceedings of the 31st Annual Convention of the American Association of Equine Practitioners, 591-602.

Arighi M., Bosu W.T.K.. (1989). Comparison of hormonal methods for diagnosis of equine cryptorchidism in horses. Equine Veterinary Sciences 9, 20-26.

Ball B.A., Conley A.J., Grundy S.A., Sabeur, K., Liu, I.K. (2008). Expression of anti-Müllerian hormone (AMH) in the equine testis. Theriogenology 69, 624-631.

Choi H.S. (1987). Immunologische Bestimmung von Sexualsteroiden zur Fertilitatskontrolle bei Rind, Schwein und Pferd. Wiener tierärztliche Monatsschrift 14-22, 47-56.

Claes A., Ball B., Almeida J., Corbin C., Conley A. (2013). Serum anti-müllerian hormone concentrations in stallions: developmental changes, seasonal variation, and differences between intact stallions, cryptorchid stallions and geldings. Theriogenology 79, 1229-1235.

Claes A., Ball B., Corbin C., Conley A. (2014). Anti-mül- 
lerian hormone as a diagnostic marker for equine cryptorchidism in three cases with equivocal testosterone concentrations. Journal of Equine Veterinary Science 34, 442-445.

Clay C.M., Clay J.N. (1992). Endocrine and testicular changes associated with season, artificial photoperiod, and the peri-pubertal period in stallions. Veterinary $\mathrm{Cli}$ nics of North American Equine Practitioners 8, 31-56.

Cox J.E., Edwards G.B., Neal P.A. (1979). An analysis of 500 cases of equine cryptorchidism. Equine Veterinary Journal 11, 113-116.

Cox J.E., William J.H., Rowe P.H., Smith J.A. (1973). Testosterone is normal, cryptorchid and castrated male horses. Equine Veterinary Journal 2, 85-90.

Cox, J.E., Edwards, G.B., Neal, P.A. (1975). Suprapubic paramedian laparotomy for equine abdominal cryptorchidism. Veterinary Record 97, 428-432.

Cox, J.E., Redhead, P.H. and Dawson, F.E. (1986) Comparison of the measurement of plasma testoserone and plasma oestrogens for the diagnosis of cryptorchidsm in the horse. Equine Veterinary Journal 18, 179-182.

Gaillard, J-L., Silberzahn, P. (1987). Aromatization of 19-norandrogens by equine testicular microsomes. Journal of Biological Chemistry 262, 5717.

Ganjam V.K., Kenney R.M. (1975). Androgens and oestrogens in normal and cryptorchid stallions. Journal of Reproduction and Fertility (Suppl) 23, 67-73.

Hartman R., Hawkins J.F., Adams S.B., Moore G.E., Fessler J.F. (2015). Cryptorchidectomy in equids 604 cases (1977-2010). Journal of the American Veterinary Medical Association 246, 777-784.

Hayes H.M. (1986). Epidemiological features of 5009 cases of equine cryptorchism. Equine Veterinary Journal $18,467-471$.

Hejmej, A., Gorazd, M., Kosiniak-Kamysz, K., Wiszniewska, B., Sadowska, J. and Bilinska, B. (2005). Expression of aromatase and oestrogen receptors in reproductive tissues of the stallion and a single cryptorchid visualised by means of immunohistochemistry. Domestic Animal Endocrinology 29, 534-547.

Hoffman B., Landeck A. (1999). Testicular endocrine function, seasonality and semen quality of the stallion. Animal Reproduction Science 57, 89-98.

Illera J.C., Silvan G. , Munro C.J., Lorenzo P.L., Illera M.J., Liu I.K.M., Illera M. (2003). Amplified androstenendione enzymeimmunoasay for the diagnosis of cryptorchidism in male horse: comparison with testosterone and estrone sulphate methods. Journal of Steroid Biochemistry and Molecular Biology 84, 377-382.

Inoue J., Cerbito W.A., Oguri N., Matsuzawa T., Sato K. (1993). Serum levels of testosterone and oestrogens in normal and infertile stallions. International Journal of Andrology 16, 155-158.

Kristina G. Lu (2005). Clinical diagnosis of the cryptorchid stallion. Clinical Techniques in Equine Practice 4, 250256.

Leung D.K., Tang, F.P., Wan, T.S., Wong, J.K. (2011). Identification of cryptorchidism in horses by analysing urine samples with gas chromatography/mass spectrometry. Veterinary Journal 187, 60-64.

McCue P. M. (2014). Diagnostic endocrinology: baseline hormone levels. In: Dascanio J., McCue P. (editors). Equine Reproductive Procedures. First edition. John Wiley \& Sons, Inc, Hoboken, NJ, USA 492-493.

Mueller P.O.E., Parks A.H. (1999). Cryptorchidism in horses. Equine Veterinary Education 11, 77-86.
Murase H., Saito S., Amaya T., Sato F., Ball B., Nambo Y. (2015). Anti-müllerian hormone as an indicator of hemicastrated unilateral cryptorchid horses. Journal of Equine Science 26, 15-20.

Muyan M., Roser J., Dybdal N., Baldwin D.M. (1993). Modulation of gonadotropin-releasing hormone-stimulated luteinizing hormone release in cultured male equine anterior pituitary cells by gonadal steroids. Biolology of Reproduction 49, 340-345.

Naden J., Amann R.P., Squires E.L. (1990). Testicular growth, hormone concentrations, seminal characteristics and sexual behavior in stallions. Journal of Reproduction and Fertility 88, 167-176.

Nett T.M. (1993). Reproductive endocrine function testing in stallions. In: McKinnon A.O., Voss J.L. (editors). Equine Reproduction. Philadelphia, Lea and Febiger, 821-824.

Odell W.D. (1989). The Leydig cel. In: De Groot L.J. (editor). Endocrinology. Volume 3. Philadelphia, W.B. Saunders Company, 2137-2145.

Ouachée E., Rossignol F. (2014). Echographie transinguinale et choix de la technique de castration chez le cryptorchide. Pratique Vétérinaire Equine 182, 62-63.

Pader K. (2006). Evaluation d'une technique de castration du cheval par laparoscopie. Thesis 2006 - Toulouse Université.

Palme R. Scherzer S., Stollar K., P. Nagy, Szenci O., Mostl E. (1998). Hormonal diagnosis of equine cryptorchidism. Wiener Tierärztliche Monatschrift 85, 188-191.

Palme R., Holzmann A., Mitterer Th. (1994). Measuring fecal estrogens for the diagnosis of cryptorchidism in horses. Theriogenology 42, 1381-1387.

Parker R.A. (2016). What is the best test for cryptorchidism. Equine Veterinary Education 28, 113-114.

Pineda M.H. (2003). Male reproductive system. In: Pineda M.H., Dooley M.P. (editors). Veterinary Endocrinology and Reproduction. Fifth edition, Iowa, Blackwell Publishing Company, 239-282.

Raeside J.I. (1978). Seasonal changes in the concentration of oestrogens and testosterone in the plasma of the stallion. Animal Reproduction Science 1, 205-212.

Schonert S., Reher M., Gruber A.D., Carstanjen B. (2012). Use of deslorelin implant for influencing sex hormones and male behaviour in a stallion - case report. Acta Veterinarie Hungarica 60, 511-519.

Silberzahn P., Rashed F., Zwain I., Leymarie P. (1984). Androstenedione and testosterone biosynthesis by the adrenal cortex in the horse. Steroids 43, 147-152.

Smith et al. (2008). Metabolic changes during gonadotropin-releasing hormone agonist therapy for prostate cancer. M.R. Smith, H. Lee, M.A. Fallon, M. Goode, A.L. Zietman, J.S. Finkelstein. Cancer 112, 2188-2194.

Stewart B.L., Roser J.F. (1998). Effects of age, season and fertility status on plasma and intratesticular immunoreactive inhibin concentrations in stallions. Domestic Animal Endocrinology 15, 129-139.

Stickle R.L., Fessler J.F. (1978). Retrospective study of 350 cases of equine cryptorchism . Journal of the American Veterinary Medical Association 172, 343-346.

Taya K., Nagata S., Tsunoda N., Nagamine N., Tanaka Y., Nagaoka K. (2000). Testicular secretion of inhibin in stallions. Journal of Reproduction and Fertility (Suppl), 43-50. 